\title{
近世相模国の大工にみる技術の継承と蓄積 \\ THE SUCCESSION AND ACCUMULATION OF TECHNIQUES FOR CARPENTERS AT SAGAMI-NO-KUNI PROVINCE IN THE EARLY MODERN PERIOD
}

\author{
山岸吉弘*
}

\section{Yoshihiro YAMAGISHI}

\begin{abstract}
In the Edo era, many carpenters lived in Ogino-mura village, Sagami-no-kuni province. It can be classified their activities into three time. Primarily, they got the technique by working together with famous carpenters. Secondly, they began to work on their own in order to have grown. Third, they are from the point of view of building industry, became indispensable to the region. It was discussed the process that the carpenters of the Edo era were inherited and accumulated the technology in this paper.
\end{abstract}

Keywords : the pre-modern period, Sagami-no-kuni province, carepntry technique, production organization 近世，相模国，大工技術，生産組織

\section{1. はじめに}

建築生産史の観点から、生産力の所在は時代の権力と密接に関連 して抢り、古代から中世にかけては国家・社寺家・武家が主な担い 手であった。被生産物としての建築における特徴として、巨額の費 用と多数の労働力を必要とする点を踏まえれば、負担することがで きるのは一部の特権階級のみであることも理解できる。結果的に、 建築する技術は特定の地域や機関に集約され、同時に職人の高度に 熟練した技を継承・蓄積する役割が果たされた ${ }^{1}$ 。。従って、上記以 外の場所で生産技術が養われるべくもなく、建築生産の中心的な主 導者が時代と共に変化しても、大工の技術は連続していたと考える べきであり、基本的には断絶することがなかった ${ }^{2)}$

一方で、近世になって社会の成熟と共に都市化の影響が農村まで 及び、生産力が全体的に底上げされると、権力との関係が相対的に 希薄となって、古代・中世とは異なる生産構造が形成される。特に、 市井の職人である大工棟梁は自ら建築生産を実現する能力を獲得し、 他者に依らない独立した営業を展開する ${ }^{3)}$ 。棟梁を中心に仲間や弟 子により集団が組織され、普請を通して次代へと技術が受け継がれ ていった。

このように、古代・中世と近世とでは建築生産の有様が大きく異 なり、建築生産史における一つの飛躍があった。それぞれの時代に 扔いて大技術は確かに継承・蓄積されており、一つの系譜として 辿ることができる。しかし、古代・中世から近世へと変革を遂げる 中で、両者にどのような関係性が認められるのか、必ずしも明確に されているとは言い難い。また、大工の隅々にまで技術が普及し得 た要因の一端に木割術や木割書の存在が挙げられようとも ${ }^{4)}$ 、なお 異なる視点から考察する余地もあろう。そのような課題を念頭に、 本稿は近世相模国を対象として大工技術の継承と蓄積について検討
する。

具体的に、現在の厚木市域を中心とした一帯に注目した（図 1)。 同地域には複数の大工家が存在していたことが知られ、中には数世 代にわたって大工を生業としていた事例もみられる ${ }^{5)}$ 。特に、荻野 村（旧荻野郷の上荻野村・中荻野村・下荻野村を便宜的に荻野村と 呼称する）には多数の大工家が集中しており、それぞれ棟札などに 足跡を残している ${ }^{6)}$ 。

\section{2. 荻野村大工の成立}

大工の居住地として荻野という地名が確認できる早い事例は、荻 野神社（厚木市上荻野）に残された貞享 4 年（1687）の木札で、「荻 野村大工三橋与兵衛・神崎久兵衛・次郎右衛門・ぶ右衛門・落合兵 右衛門」と記されている ${ }^{7)}$ 。同木札には、「大工飯山村頭領西谷半右

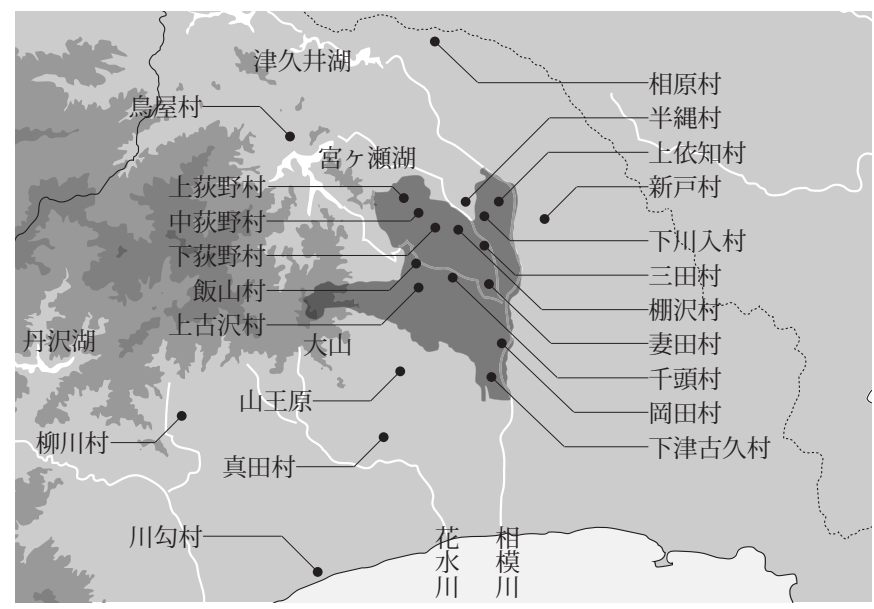

図 1 厚木市域と村々の所在地

本稿は, 部分的に次の既発表内容を含んでいる。拙稿「近世相模国荻野村の大工」『日本建築学会大会学術講演梗概集』, 日本建築学会, 2016 年 8 月。

日本大学工学部 助教・博士(建築学) Assist. Prof., College of Engineering, Nihon Univ., Dr.Arch. 
衛門・脇同名甚五左衛門・同名十郎左衛門・同名拾三郎」ともあり、 普請は棟梁・脇棟梁を始め西谷姓の大工を中心に行われたことが知れ る。飯山村（厚木市飯山）の西海（西谷）家は戦国期にまで遡る事跡 を持つ一族で、半右衛門や圭兵衛が棟梁の地位にあり、当地を代表す る大工家の一つであった ${ }^{8)}$ 。荻野村大工の三橋与兵衛や神崎久兵衛な どは、西海家の棟梁である半右衛門の下で仕事に従事した。

西海家以外にも、有力な大工家による普請に荻野村大工が関与する 事例を確認することができる。延享 2 年（1745）の宝泉寺棟札（厚 木市上依知）には「中荻野住花上宗右衛門広則」や「荻野小山氏定七 郎為則」とあり、荻野村大工が普請に参加している ${ }^{9)}$ 。また、「棟梁 山王原住明王太郎」とも記されていることから、大工棟梁を務めた明 王太郎を中心に編成された組織であることが分かる。大山山麓の山王 原（伊勢原市上粕屋）に居住した手中明王太郎もまた、中世以前にま で由緒を辿ることのできる大工である ${ }^{10)}$ 。荻野村大工の花上宗右衛 門や小山定七郎は、明王太郎による指揮の下で任に当たった。

その他、天明 7 年 (1787) の川勾神社棟札（中郡二宮町川匂）には、 「大山遍手中明王太良忌部景直・同景喜」や「門人石井庄助・神崎吉 左衛門・小川庄蔵・守屋傳八」とあり、明王太郎とその一門による普 請であることが知れる ${ }^{11}$ 。明王太郎は荻野村より多く弟子を採って おり ${ }^{12)}$ 、少なくとも小川庄蔵を除く三名の門人は荻野村の出自である。

このように、荻野村大工の活動は 17 世紀後半から確認することが できる。勿論、それ以前において荻野村やその周辺にも大工は存在し ていただろう。例えば、諏訪神社（厚木市上古沢）で行われた普請に は下古沢村の大工である三左衛門が関与している ${ }^{13)}$ 。しかし、17 世 紀前半から中葉にかけて、村々に大工（いわゆる宮大工）はそれほど 多くはなかったのではないか。慶安 3 年（1650）には田中明王太郎 影吉が及川村まで出向き、諏訪神社（厚木市下川入）の普請を行って いる ${ }^{14)}$ 。更に遡って 16 世紀末の天正年間では、遍照院（厚木市妻田） の普請に駿河の大工や小田原の鳥が乎び寄せられている ${ }^{15)}$ 。

荻野村大工にとって、荻野神社の普請は一つの転換点に位置付けら れよう。村の鎮守を造営するに当たり、三橋与兵衛以下五名の荻野村 大工が結集したものの、技術的に困難があった。だからこそ、棟梁と して西谷 (西海) 半右衛門を迎え、同家四名の大工が参加する組織が 編成された。一方で、未熟ながらも荻野村大工が確かに存在し、社会 的に顕在化してきていることも疑いない。農村生活の範囲にあった農 民の技術が、専門職人としての大工の技術へと進化を遂げつついよう。

江戸時代中期の事例を参照するに、荻野村大工は既に高い実力を備 えた西海家や手中家の大工棟梁と共同していたことが確認できた。そ れより、技術の伝播が大工間であったことが想定されよう。つまり、 特定の家系に蓄積され洗練されてきた中世以来の技術が、近世以後は 共同して行われる普請の中で他家の大工に継承され、やがては一般化 していく。そのような理解が妥当であることの確証を得るために、実 力を備えた荻野村大工が独立し、発展していく過程を辿る。

\section{3. 荻野村大工の成長}

荻野村大工が棟梁として普請を主導的に行う事例に、八幡神社（厚 木市三田）が挙げられる。安永 4 年（1775）の棟札には「当国上荻 野村大工棟梁曽根源左衛門居続」とあり、荻野村大工の曽根源左衛門 が棟梁を務めている ${ }^{16)}$ 。その他に、「同国国下荻野新宿彩色難波兵吉藤

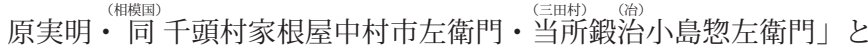

して諸職人が共同している。各々の居住地である下荻野新宿（厚木 市下荻野)・千頭村 (同飯山) ・三田村（同三田）は、いずれも曽根 家が所在する上荻野村（同上荻野）の近隣に当たる。地域に祀られ る氏神の社殿を造営するために、源左衛門は在地の職人をまとめて 集団を組織した。

曽根家の大工は、源左衛門に続いて久次郎や勘右衛門を確認する ことができる（表 1)。少なくとも源左衛門の頃から後は、大工を家 業としてきたのだろう（前提として農民でもある）。現場を共にする ことで親から子へと次世代に技術が相伝され、同家において約 80 年 の期間にわたって大工という職能が再生産された。

荻野村やその周辺では、曽根家と同様に複数代にわたって大工を 生業としていた家系がある。花上家の大工は、明王太郎が棟梁を務 めた宝泉寺の普請に参加した宗右衛門を始め、幕末までに丈右衛 $\square$. 豊次郎・市蔵（棚沢村に居住する）・秀次郎の各大工が誕生した (表 2)。 それより前の貞享年間に行われた荻野神社の普請では、屋根屋とし て花上市郎兵衛が参加しており、大工への転身も考えられよう（馬 場村は荻野村の内にある)。守屋家の大工は、同じく川勾神社の普請 を手中家と共同した傳八から、久米矩孝・条矩親・弥太郎・理喜造・ 左京矩義と続く（表 3)。このように、明王太郎の技術を花上宗右衛 門や守屋傳八が目の当たりにする機会を得て、その後は自家薬籠中 の物として次世代へ伝えていった。

中には明王太郎の門人として研鑽を積んだ後に、手中家の養子と なって襲名し、棟梁の職を継いだ事例もみられる。石井家の大工と して、天明年間に庄兵衛と庄助の存在を確認することができ、その 他にも義兵衛や七良左衛門がいる（表 4)。天明 8 年（1788）に行 われた稲荷神社（厚木市下津古久）の普請で、庄助は「大山匠手中 明王太郎門人棟梁荻野村石井庄助徳宅」として棟梁を務めており、 肩書きには明王太郎の門人であることを記す ${ }^{17)}$ 。それより十八年前 の安永元年（1772）に、庄助は荻野村から明王太郎の下へ弟子入り している ${ }^{18)}$ 。その間に技術を習得し、年季が明けて帰郷したことが 窥えよう。その後、再び手中家に戻り、信直を継ぐ信景として明王 太郎となった ${ }^{19)}$ 。

落合家の大工は、西海家の大工を棟梁として荻野村大工が従事し た荻野神社の普請において大工の兵右衛門と屋根屋の源太郎が参加 し、その他に源七郎廣則・七左衛門・源七を確認することができる （表 5)。更に、棚沢村(厚木市棚沢)に居住した橘川家の大工は、寛政 10 年（1798）の棟札が残る八幡宮（相模原市緑区相原）の普請に参加 した富治郎義房を始め、富三郎成政・民五郎永吉・十次郎・覚次郎・ 与右衛門成政まで多数が名を残している（表 6)。その最初となる富 治郎は、「大棵梁柳川右兵衛安則相州愛甲郡半原村」の助工として 普請に携わった後に ${ }^{20)} 、 今$ 度は大工棟梁として文化元年（1804）に 聖眼寺（厚木市三田）を手掛けている ${ }^{21)}$ 。半原村の柳川右兵衛は、 江戸幕府作事方の大工を務め、一代のみということで柏木姓を賜り、 その後は矢内姓となって幕末まで続く大工家の初代として活躍し

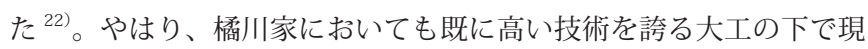
場を経験し、その後に独立して地域の仕事を請け負うようになる。

隣村の及川村には桐生家の大工が居住し、期間は短いものの旺盛 な仕事ぶりを確認することができる（表 7)。遍照院の枌や隅木には、 宝暦 8 年（1758）の年号と共に「中野喜衛門門弟棟梁秋山三四郎門 弟及川村桐生」や「及川村長五郎」と記されており、桐生家の活動 
表 1 曾根家の大工

\begin{tabular}{|c|c|c|c|c|c|c|c|c|}
\hline 職名等 & 姓名 & 居住地名 & 建物名 & 所在地名 & 和暦 & 西暦 & 史料 & 出典 \\
\hline 大工棟梁 & 曽根源左衛門居続 & 相模国上荻野村 & 八幡神社 & 厚木市三田 & 安永 4 年 & 1775 & 棟札 & 社寺 \\
\hline 衆工 & 曽根久次郎 & 荻野邑 & 三島神社 & 厚木市岡田 & 寛政 11 年 & 1799 & 棟札 & 社寺 \\
\hline 大工棟梁 & 曽根久次良 & 荻野横林 & 梅沢氏宅 & 厚木市山際 & 文化 10 年 & 1813 & 棟札 & 民家 \\
\hline 大工 & 曽根勘右卫門都栄 & ヨキノ & 吉祥寺 & 厚木市岡津古久 & 安政 2 年 & 1855 & 厨子内墨書 & 寺院 \\
\hline 大工棟梁 & 勘右衛門 & 上荻野横林村 & 子安神社 & 厚木市岡津古久 & 安政 4 年 & 1857 & 棟札 & 神社 \\
\hline \multicolumn{9}{|c|}{ 表 2 花上家の大工 } \\
\hline \multirow[t]{2}{*}{ 屋ねや } & 花上市郎兵衛 & 馬場村 & 荻野神社 & 厚木市上荻野 & 貞享 4 年 & 1687 & 木札 & 社寺 \\
\hline & 花上宗右門広則 & 中荻野住 & 宝泉寺 & 厚木市上依知 & 延享 2 年 & 1745 & 棟札 & 集 2 \\
\hline \multirow[t]{2}{*}{ 衆工 } & 花上丈右衛 $\square$ （門） & 荻野邑 & 三島神社 & 厚木市岡田 & 寛政 11 年 & 1799 & 棟札 & 社寺 \\
\hline & $\begin{array}{l}\mid \text { 花上豊次郎 } \\
\text { 花上古蔵 }\end{array}$ & $\begin{array}{l}\text { 荻野村 } \\
\text { 相沢村 }\end{array}$ & 清源院 & 厚木市三田 & 天保 3 年 & 1832 & 棟札 & 集 2 \\
\hline 大工 & 花上秀次郎 & 荻野 & 白山姫神社 & 相模原市南区新戸 & 天保 10 年 & 1839 & 棟札 & 相模 \\
\hline \multicolumn{9}{|c|}{ 表 3 守屋家の大工 } \\
\hline 門人 & 守屋傳八 & & 川勾神社 & 中郡二宮町川匂 & 天明 7 年 & 1787 & 棟札 & 二宮 \\
\hline \multirow[t]{3}{*}{ 番匠之小工・別番匠 } & 守屋久米矩孝 & 荻野沢村住人 & 白山姫神社 & 相模原市南区新戸 & 文化 5 年 & 1808 & 棟札 & 相模 \\
\hline & 守屋久米矩孝 & & 柳川不動堂 & 秦野市柳川 & 文化 6年 & 1809 & 棟札 & 建築 \\
\hline & 守屋条源矩親 & & 長松寺 & 相模原市南区新戸 & 文政 12 年 & 1829 & |棟札 & 相模 \\
\hline 大工連名 & 守屋弥太郎 & ヨキノ & & & & & & \\
\hline $\begin{array}{l}\text { 大工 } \\
\text { 大工 }\end{array}$ & 森屋理喜造 & 荻野 & 白山姫神社 & 相模原巾南区䄬尸 & 大保 10 年 & 1839 & 惈札 & 相模 \\
\hline \multirow{2}{*}{ 宮番匠棟梁 } & 埋㷊屋左京源矩義 & $\begin{array}{l}\text { 上狄野村 } \\
\text { 相州愛甲荻野村住 }\end{array}$ & & & & & & \\
\hline & 森屋弥太郎 & & 日枝神社 & 厚木市関口 & 嘉永 7 年 & 1854 & 棟札 & 集 1 \\
\hline 大工 & 力造 & 荻野 & 山際神社 & 厚木市山際 & 慶応元年 & 1865 & 古記録 & 集 1 \\
\hline \multicolumn{9}{|c|}{ 表 4 石井家の大工 } \\
\hline & 石井庄兵衛 & 荻野公所村 & 遍照院（妻田薬師） & 厚木市妻田 & 天明 6 年 & 1786 & 木札 & 社寺 \\
\hline 門人 & 石井庄助 & & 川勾神社 & 川勾 & 天明 7 年 & 1787 & 棟札 & 二宮 \\
\hline \multirow{4}{*}{$\begin{array}{l}\text { 大山匠手中明王太郎門人棟梁 } \\
\text { 相陽大山棟梁手中明王太良忌 } \\
\text { 部景直門人棟梁 }\end{array}$} & 石井庄助徳宅 & 荻野村 & 稲荷神社 & 厚木市下津古久 & 天明 8 年 & 1788 & 木札 & 社寺 \\
\hline & 石井義兵衛忌部吉敦 & 中荻野村住 & 日枝神社（旧山王社） & 厚木市下荻野 & - & - & |棟札 & 集 1 \\
\hline & 同庄助忌部信景 & & & & & & & \\
\hline & 石井七良左衛門 & 当所 & 聖眼寺 & 厚木市三田 & 文化元年 & 1804 & 棟札 & 社寺 \\
\hline \multicolumn{9}{|c|}{ 表 5 落合家の大工 } \\
\hline （大工） & 落合兵右衛門 & & 荻野神社 & 厚木市上荻野 & 貞享 4 年 & 1687 & 木札 & 社寺 \\
\hline \multirow[t]{4}{*}{ （屋ねや） } & 落合源太郎 & & & & & & & \\
\hline & 落合源七郎廣則 & 荻野村 & 自興院 & 秦野市北矢名 & 寛保元年 & 1741 & 棟札 & 史料 \\
\hline & 落合七左衛門 & 当所 & 聖眼寺 & 厚木市三田 & 文化元年 & 1804 & 棟札 & 社寺 \\
\hline & 落合源七 & 荻野 & 長福寺 & 厚木市寿町 & 元文元年 & 1864 & 棟札 & 民俗 \\
\hline \multicolumn{9}{|c|}{ 表 6 橘川家の大工 } \\
\hline \multirow[t]{2}{*}{ 助工 } & 橘川冨治郎 & 棚沢村 & 八幡宮 & 相模原市緑区相原 & 寛政 10 年 & 1798 & 棟札 & 相模 \\
\hline & 橘川富三郎成政 & & - & - & 享和元年 & 1801 & - & 産業 \\
\hline 大工棟梁 & 橘川冨次良儀房 & 棚沢村 & 聖眼寺 & 厚木市三田 & 文化元年 & 1804 & 棟札 & 社寺 \\
\hline \multirow[t]{4}{*}{ 大工 } & 橘川冨三郎 & 棚沢村 & 難波氏宅 & 厚木市下荻野 & 文政元年 & 1818 & 絵図 & 民家 \\
\hline & 橘川富三郎成政 & & & & & & & \\
\hline & 橘川民五郎 & & - & - & 文政 8 年 & 1825 & - & 産業 \\
\hline & 橘川十次郎 & & & & & & & \\
\hline 大工棟梁 & 橘川能登正橘成政 & & & & & & & \\
\hline \multirow[t]{3}{*}{ 脇棟梁 } & 橘川民五郎永吉 & & 清源院 & 厚木市三田 & 天保 3 年 & 1832 & 棟札 & 集 2 \\
\hline & 橘川覚次郎 & 棚沢村 & & & & & & \\
\hline & 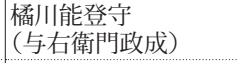 & & - & - & 天保 12 年 & 1841 & - & 産業 \\
\hline \multirow[t]{2}{*}{ 大工 } & 橘川与右衛門 & 棚沢村 & 日枝神社 & 厚木市関口 & 天保 13 年 & 1842 & 棟札 & 集 1 \\
\hline & 橘川与右衛門 & 棚沢村 & 小野神社 & 厚木市小野 & 嘉永 2 年 & 1849 & 棟札 & 集 1 \\
\hline 大工頭領 & 橘川能登正源成政 & 棚沢村 & 八幡社 & 厚木市三田 & 文久 4 年 & 1864 & - & 神社 \\
\hline \multicolumn{9}{|c|}{ 表 7 桐生家の大工 } \\
\hline 秋山三四郎門弟 & 桐生長五郎 & 及川村 & 遍照院（妻田薬師） & 厚木市妻田 & 宝暦 8 年 & 1758 & 桁・隅木墨書 & 社寺 \\
\hline 大工棟梁 & 桐生長五郎 & & 金田神社 & 厚木市金田 & 明和 7 年 & 1770 & 棟札 & 社寺 \\
\hline \multirow[t]{2}{*}{ 秋田 (山カ) 三四郎門人 } & 桐生長五郎光興 & 及川村 & 鳥屋諏訪神社 & 相模原市緑区鳥屋 & 安永 4 年 & 1775 & 棟札 & 津久 \\
\hline & 桐生長五郎 & & 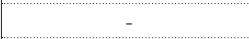 & - & 安永 9 年 & 1780 & - & 産業 \\
\hline 大工 & 桐生長五郎光興 & 及川村 & 八幡神社 & 厚木市下依知 & 天明 8 年 & 1788 & 棟札 & 神社 \\
\hline
\end{tabular}

「出典」の略記は以下の通り。

集 1 : 『厚木市史史料集 (1) 神社編』(厚木市史編さん委員会、1972 年 10 月)

集 2 ：『厚木市史史料集（2）寺院編』（厚木市史編さん委員会、1973 年 1 月）

神社：『神社の文化財』(厚木市教育委員会、1974 年 3 月)

寺院：『寺院の文化財』(厚木市教育委員会、1974 年 3 月)

産業：『厚木産業史話』(厚木市役所、1976 年 3 月)

民家：『厚木の民家 (2)』(厚木市教育委員会、1 978 年 3 月)

民俗：『厚木の民俗 1』（厚木市教育委員会、1981 年 3 月）
相模：『相模原市文化財現況調査報告書』（相模原市文化財現況調査会、1984 年 3 月)

史料：『秦野市史第一巻古代・中世 社寺史料』（秦野市、1985 年 3 月） 社寺：『厚木の社寺建築』(厚木市、1987 年 3 月)

津久：『津久井郡文化財 神社編』(津久井郡広域行政組合、1987 年 3 月）

二宮：『二宮町史別編 寺社・金石文』(二宮町、1994 年 3 月)

建築：『秦野市の寺社建築』(秦野市教育委員会、2002 年 3 月) 
を知る最初期の手掛かりとなる ${ }^{23)}$ 。桐生家の大工の外に「大工棟梁 当村秋山三四郎」の名前も記されており、秋山三四郎が棟梁であった。 更に、三四郎は中野喜右衛門の門弟であり、桐生家の大工はその孫 弟子に当たる。三四郎は真田神社本殿（平塚市真田）の普請も手掛 けており、寛延 2 年（1749）の棟札には「工匠武野城下中野喜右門 門弟秋山三四郎」と同じく中野喜右衛門門弟とある ${ }^{24)}$ 。つまり、妻 田村の三四郎は遠方の城下（江戸か）にいる中野喜右衛門に弟子入 りし、仕事を覚えて帰郷した後、更に及川村の長五郎が三四郎の弟 子となった。鳥屋諏訪神社本殿(相模原市緑区鳥屋)に残された安永 4 年（1775）の棟札には、「大工箖花町中野喜右衛門秋田三四郎門人及 川村桐生長五郎光興」という三名の名前を確認することができる ${ }^{25)}$ 。 別に残された板の墨書では長五郎が「棟梁」であったことを記して おり、恐らくは喜右衛門や三四郎は普請に携わっていない。つまりは、 棟梁である長五郎の技術的な系譜が、肩書きとして添えられている ことが分かる。

江戸時代中期の事例を参照するに、荻野村や周辺の村々で大工を 生業とする複数の家系を確認することができた。各家の多くで既に 実力を備えた棟梁と共同する現場を踏んでおり、技術の伝播や継承 のあったことが窥える。その後は、一族の中で仕事が伝えられ、家 業として成立する。その結果、地域の大工が棟梁となり、地域の職 人により集団が組織され、地域の社寺で普請が行われるようになる。 荻野村やその一帯において多数の大工が存在し得た背景として、技 術の継承と蓄積の果たされていたことが理解できよう。

\section{4. 荻野村大工の展開}

実力を備えた村々の大工は、自ら普請の体制を構築することがで きるようになる。文化元年（1804）の聖眼寺棟札には、「棚沢村大 工棟梁橘川冨次良儀房 - 桐州半原村脇中嶋小平次 - 棚沢村和田儀兵衛 · 当所落合七左衛門 · 当所井上勘衛門 - 当所石井七良左衛門 - 当所杣 佐藤与兵衛 ・ 当所木挽曾根次兵衛」とあり、棚沢村の橘川家を中心 に地元の大工や杣・木婏が集まって集団は組織された。落合・井上・ 石井の各大工は「当所」とあるものの、抢そらくは荻野村が居住地 であろう。

また、寛政 11 年（1799）の三島神社棟札（厚木市岡田）には「棟 梁工匠相州愛甲郡半縄村天野幸八藤原政之」とあり、半縄村（愛甲 郡愛川町中津）の大工が棟梁を務めた ${ }^{26)}$ 。幸八の下には、「脇棟梁

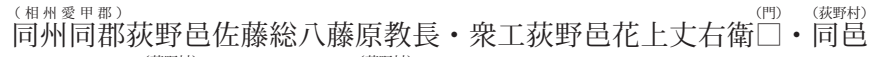

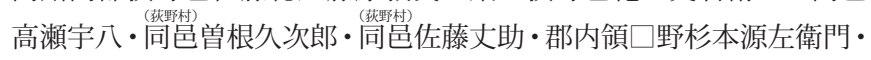
相州愛甲郡船子邑菊地義兵衛」として、脇棟梁の佐藤総八を始め五 人の荻野村大工が参加している。総八と丈助は同じ佐藤姓であり一 族と考えられるが、詳細を知る手掛かりがない。棟梁・脇棟梁・衆 工の差には、個人的な技能や大工技術の程度も少なからず反映しょ うが、政治的・社会的事情も影響する（例えば、施主の意向は人選 を大きく左右しょう)。三島神社の普請では半縄村大工が棟梁である ものの、体制の構築を量的な側面から実現させていたのは佐藤・花上・ 高瀬・曽根等々の荻野村大工であった。

このように、地域に蓄積・保持された生産力により社寺の堂宇は 新造・修造されており、特に荻野村を中心とする一帯は人的資源の 供給源として機能していた。一方で、在地の大工が果たすべき重要 な役割に、社寺建築だけでなく村の屋敷など住宅建築を引き受ける
という観点も見逃せない。三島神社では衆工の一人として参加して いた曽根久次郎は、文化 10 年（1813）に梅沢氏宅の「文庫蔵」を 棟梁として完成させており、棟札には「荻野横林大工棟梁曽根久次良」 と記されている ${ }^{27)}$ 。また、棚沢村の橘川冨三郎は、文政元年（1818） に荻野村の難波氏宅の「質蔵・居宅・物置・下屋」などを完成させ、 「棚沢村大工橘川冨三郎」の記名がある絵図を残している ${ }^{28)}$ 。いわゆ る宮大工と呼ばれるような久次郎や富三郎ではあるが、社寺の堂宇 だけでなく居宅なども手掛けていたことが分かる。

守屋家の大工は活動に特徴があり、傳八が明王太郎と川勾神社を 手掛けた後、主な現場となった白山姫神社や長松寺はいずれも新戸 村（相模原市南区新戸）に所在する。文化 5 年（1808）の白山姫神 社棟札には「神祇官番匠棟梁前長山金吾源矩稠」と、文政 12 年 (1829) の長松寺棟札には「御宮番匠当山棟梁当国足柄上郡柳川住人前長山 左衛門金吾匠源矩稠」と、それぞれ棟梁の名前が記されており、ど ちらも柳川村 (秦野市柳川) の長山左衛門が務めている ${ }^{29}$ 。更に、 天保 10 年（1839）の白山姫神社棟札には「大工当所棟梁長山左門」 とあり、同じく長山姓の棟梁であることが分かる。ここでは柳川村 ではなく「当所」の大工と記されていることから、新戸村に移住し たことも想定されよう。つまり、白山姫神社や長松寺が所在する新 戸村と長山家の間には特別な関係性が認められ、普請を継続的に担 当していた。そのような施主（地域社会）から特別視される長山姓 の大工を補佐していたのが、守屋家や花上家など荻野村の大工とい える。

厚木市域の範囲で、大工による太子講は四つ確認されており、そ の内の一つは荻野村にあった ${ }^{30)}$ 。幕末から明治維新後直ぐの頃に筆 写されたという「太子講連名控簿」には、25名の荻野の大工が記さ れて抢り、他の地域と比較しても多い ${ }^{31}$ 。その中には、守屋（森家） 家の大工であろう理喜蔵の名前も含まれている。荻野村大工の勢い は、時代を経てもなお衰えることはなかった。

江戸時代後期の事例を参照するに、多数の大工が居住していた荻 野村を中心とする地域の役割として、二つの側面を指摘することが できた。一つは、各地の社寺建築普請において、生産組織の形成を 数量という観点から実現させること。一つは、当地の住宅建築普請 において、棟梁として全ての責任を負い施主の要求に応えること。 地域社会に必要な建築生産を果たすべくあり、村々の大工の存在意 義を具体的に確認することができる。

\section{5. 近世相模国における大工の位置付け}

大工技術の継承と蓄積という問題について、近世相模国を対象に 考察した。その結果、農村大工の活動の変遷を、成立・成長・展開 の各段階に区分して理解することができた（図 2)。荻野村を中心と する一帯には、大工を生業とする複数の家系が存在した。それらの 多くで、既に高い実力を備えた大工が棟梁を務める普請に参加して いた。現場で学習する機会のあったことから、村落の外部から技術 の摂取されていたことが想定された（成立期）。その後、各々の家系 で大工という職能が再生産され、仕事が継承されていく。身に付け たものが次代へと受け継がれることにより、村落の内部に技術が蓄 積されるようになる（成長期）。やがて、棟梁を始め普請のための組 織を村々の大工により構成することができるようになる。村落内外 の社寺建築や住宅建築など、地域の建築生産を実現するために必要 


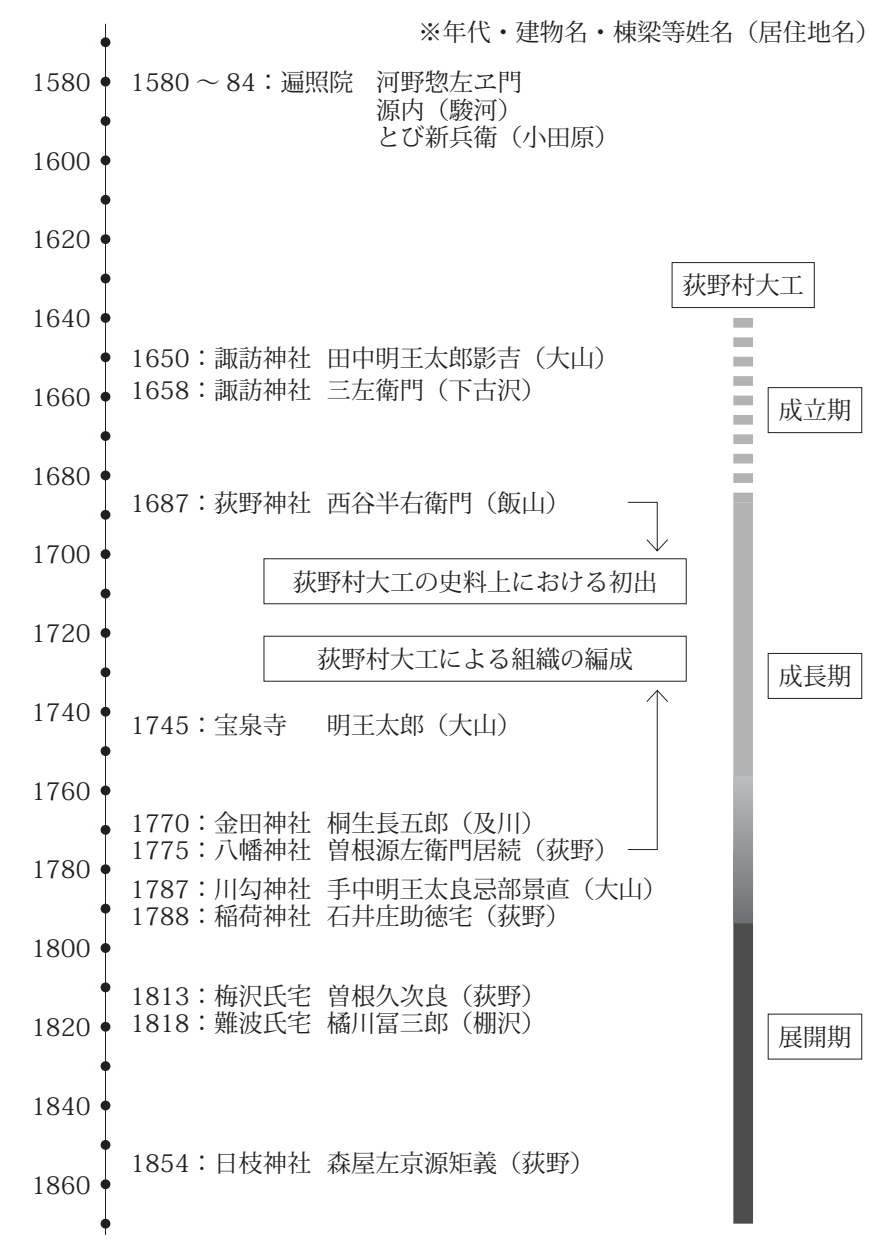

図 2 荻野村一帯の普請状況と荻野村大工の推移

となる専門的な労働力を、量・質の両面から供給するまでに至る（展 開期)。

改めて、技術の継承や蓄積は人を媒介に成し遂げられていたとい えよう。地縁による人的関係性の内に技術が伝播され、血縁による 人的関係性の内に技術が保持される。であるならば、個人による主 観が建築という造形に少なからず反映することが想定される（例え ば、現代的な視点でいうところの作家性の表出)。大工の技術的な系 譜を踏まえた建築の差異を指摘し得る可能性があるものの、その解 明は今後の課題である。

な㧍、本稿の該当する学問領域に扔いては既に多くの蓄積があり、 さまざまな報告が行われている。特に、近畿地方を対象とする研究 が目覚ましく、成果は一定の水準に達したといえよう ${ }^{32}$ 。次なる研 究の段階として、個々の事例を踏まえた歴史事象の一般化が目指さ れなければならない ${ }^{33)}$ 。それは容易でないが、都度に提案すること も必要であろうことから若干の私見を述べる。例えば、京や大坂の 都市域ではともかく畿内・近江の農村域に扔いても大工組などが形 成され、大工は社会的な枓組みの中に位置付けられている ${ }^{34)}$ 。権力 による支配構造に生産組織が組み込まれて扔り、その点より戦国時 代からの構造を汲むとも理解できる。翻って相模国の大工をみるに、 決して個々の活動を規定するような外圧は看取されない。普請の体 勢や手段を獲得する方途も、地域社会の特性を巧みに利用して棟梁 が自ら工夫しているようである ${ }^{35)}$ 。つまり、荻野村大工には変遷す る契機が内在していたといえよう。だからこそ、荻野村大工に㧧
ても成立期・成長期・展開期の区分を設定することができた。

注

1）例えば、古代の木工寮や中世の座が挙げられ、特に飛騨工という技術者集 団の成立理由を考えると分かりやすい（田辺泰／渡辺保忠「飛騨工考」『日 本建築学会論文集』第 39 号、日本建築学会、1949 年 11 月)。

2）渡辺保忠「日本に打ける古代的建築生産構造とその中世への発展過程につ いて」『建築雑誌』第 788 号、日本建築学会、1952 年 7 月。

3）永井規男「歴史のなかの建築生産システム」『新建築学大系 44 建築生産シ ステム』、彰国社、1982 年 10 月、78～81 頁。

4）中川武「建築設計技術の変遷」『講座・日本技術の社会史 第 7 巻 建築』、 日本評論社、1983 年 12 月、94 96 頁。

5) 例えば、西海家 (飯山村)・桐生家 (及川村)・憰川家 (棚沢村) などがある (神 奈川県教育庁生涯学習部 編『神奈川県の近世社寺建築 神奈川県近世社寺 建築調査報告書 本文篇、神奈川県教育委員会、1993 年 3 月、1 $44 \sim 145$ 頁)。

6）鈴村茂『厚木の職人史全、県央史談会厚木支部、1980 年 12 月、38～40 頁。

7）秘書部市史編さん室 編『厚木の社寺建築』、厚木市、1987 年 3 月、 115 頁。

8）前掲書、183〜187 頁。なお、西海家の活動を記録する古い史料として、 天正 3 年（1573）の棟札写しがある（厚木市史編さん委員会 編『厚木市 史史料集（4）地誌編』、厚木市役所、1973 年 10 月、111頁)。林村（厚 木市林) の三社明神社 (現在の林神社)に残されたもので、「工西谷和泉守」 と記されていたらしい。また、江戸時代になって、寛永 2 年 (1625) に は戸兵衛が飯出神社（厚木市酒井）を、寛永 18 年（1641）には圭兵衛が 本禅寺（厚木市飯山）を、それぞれ手掛けて扔り、棟札に名前を残してい る（秘書部市史編さん室 編『厚木の社寺建築』、厚木市、1987 年 3 月、 115 頁)。その後、寛文 12 年（1672）の観音堂厨子小札（厚木市飯山）によ ると、半右衛門が大工棟梁を務めた普請に圭兵衛と三郎兵衛が加わって、 三名の西海家の大工が同じ現場に出ていた（前掲書、 $74 \cdot 128$ 頁）。この 頃までに、西海家は大工を家業とする体制を着実なものとして整えていた といえよう。

9）『厚木市史史料集 (2) 寺院編』、厚木市史編さん委員会、1973 年 1 月、61 頁。

10) 手中正「手中明王太郎と大工文書そして明王太郎敏景」(『伊勢道中日記 旅 する大工棟梁』、平凡社、1999 年 11 月、136〜140 頁)。な技、明王太 郎の事跡を具体的に辿ることのできる現存最古の史料は、光明寺仁王門像 （平塚市南金目）の体内墨書で、延徳 5 年（1493）の年号と共に「大工明 王太郎末孫吉宗」と記されている（平塚市文化財保護委員会 編『平塚市文 化財調査報告書第 25 集』、平塚市教育委員会、1 990 年 3 月、 5 頁)。また、 天文 16 年 (1547) の駒形神社棟札（平塚市岡崎）や天文 20 年（1551） の高部屋神社棟札（伊勢原市下糟屋）にも、明王太郎の名前を確認するこ とができる(『平塚史市 1 資料編 古代・中世』、平塚市、1985 年 4 月、564 頁。 伊勢原市史編集委員会 編『伊勢原市史古代・中世資料編』、伊勢原市、1991 年 3 月、664 頁)。一方で、明王太郎の活躍は江戸時代に入ってからが目 覚ましく、拠点としていた大山寺で行われた元禄期の普請では、明王太郎 を中心に在地の大工による集団が組織されており、確実に地域を代表する 棟梁へと成長を遂げていることが窥える（拙稿「近世相模国大山寺普請の 内容的特質と明王太郎の行動及び役割について」『日本建築学会計画系論 文集』第 644 号、日本建築学会、2009 年 10 月)。

11)『二宮町史別編 寺社・金石文』、二宮町、1994 年 3 月、474 頁。

12）拙稿「近世在郷寺社普請における明王太郎の棟梁職の獲得とその背景につ いて」『日本建築学会計画系論文集』第 650 号、日本建築学会、2010 年 4 月。

13) 秘書部市史編さん室 編『厚木の社寺建築』、厚木市、1987 年 3 月、 115 頁。

14) 前掲書、159 頁。

15)前掲書、16 17 頁。

16) 前掲書、118 119 頁。

17)前掲書、153 頁。

18）「大工弟子奉公人請状之事（十二年季）（中欠）」(手中家資料 172）。 大工弟子奉公人請状之事

一、私忰庄助卜申男、行年拾式才二相成候二付、其元大工職御弟子奉公差 出シ申候処実正也、年季義当辰ノ七月より来ル印ノ七月迠中年拾式年季二 相定申候、

（中欠）

一、宗旨之義八代々真言宗二て、同村灌頂院檀那縁無御座候、御 公儀様 御法度之宗門二て八無御座候、為後日大工弟子奉公人請状、仍て如件 安永元年辰七月日 相州中荻野村

$$
\text { 人主八三郎间 }
$$




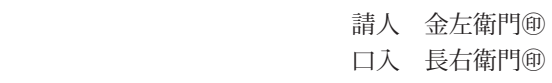

大山寺大工棵梁 手中明王太郎殿

資料名 - 資料番号は、『相模国大山大工棟梁手中家資料所在目録稿』（神奈 川県教育委員会、1997 年 3 月）に準ずる。

19) 手中正「手中明王太郎と大工文書そして明王太郎敏景」(『伊勢道中日記 旅 する大工棟梁』、平凡社、1999 年 11 月、133～134 頁。

20 『相模原市文化財現況調查報告書』、相模原市文化財現況調査会、1984 年 3 月、12 頁。

21) 秘書部市史編さん室 編『厚木の社寺建築』、厚木市、1987 年 3 月、34 頁

22）鈴木光雄『幕府作事方 柏木、矢内匠家半原宮大工矢内匠家匠歴譜』、2009 年 6 月、9 11 頁。

23) 秘書部市史編さん室 編『厚木の社寺建築』、厚木市、1987 年 3 月、 $17 \sim 18$ 頁。

24）平塚市文化財保護委員会 編『平塚市文化財調查報告書 第 27 集』、平塚市 教育委員会、1992 年 3 月、103頁。

25) 津久井郡文化財調査研究会 編『津久井郡文化財 神社編』、津久井郡広域行 政組合、1987 年 3 月、46 頁。

26) 秘書部市史編さん室 編『厚木の社寺建築』、厚木市、1987 年 3 月、125 頁。

27）厚木市古民家調査委員会 編『厚木市文化財調查報告書 第 20 集 厚木の民 家 (2)』、厚木市教育委員会、1978 年 3 月、64 頁。

28) 前掲書、 $124 \cdot 126$ 頁。

29)『相模原市文化財現況調查報告書』、相模原市文化財現況調査会、1984 年 3 月、 $33 \cdot 48$ 頁。

30) 厚木市文化財協会 編『厚木の民俗 3 講 厚木市文化財調查報告書第 26 集』、 厚木市教育委員会、1983 年 3 月、220 頁。

31) 鈴村茂『厚木の職人史全』、県央史談会厚木支部、1980 年 12 月、78～80 頁。

32) 例えば、川上貢編『近世建築の生産組織と技術』（中央公論美術出版、1984 年 10 月）が挙げられる。

33) 前掲書に対して、大河直躬「書評川上貢編『近世建築の生産組織と技術』」 （『建築史学』、建築史学会、1985 年 3 月、138～139 頁）は成果の意義 を認めつつも「より一般的、総合的な研究課題としてまとめられることを 期待したい」とする。

34) 吉田高子「江戸時代中・後期における六ヶ国農村大工組について」『近世 建築の生産組織と技術』、中央公論美術出版、1984 年 10 月、195～248 頁。

35) 例えば、明王太郎が広範囲にわたって普請を手掛けることのできた要因と して、大山参詣の流行を指摘した（拙稿「近世在郷寺社普請における明王 太郎の棟梁職の獲得とその背景について」『日本建築学会計画系論文集』 第 650 号、日本建築学会、2010 年 4 月、909 914 頁)。

出典

図 $1 \sim 2$ 著者作成。

付記

・査読者のご教示により、表 3 中の守屋久米矩孝（柳川不動堂）に関して加筆・ 修正した。

・本稿は、JSPS 科研費（26820270）による研究成果の一部である。 


\section{THE SUCCESSION AND ACCUMULATION OF TECHNIQUES FOR CARPENTERS AT SAGAMI-NO-KUNI PROVINCE IN THE EARLY MODERN PERIOD}

\section{Yoshihiro YAMAGISHI*}

* Assist. Prof., College of Engineering, Nihon Univ., Dr.Arch.

In the Edo era, many carpenters lived in Ogino-mura village, Sagami-no-kuni province. It can be classified their activities into three time. Primarily, they got the technique by working together with famous carpenters. Secondly, they began to work on their own in order to have grown. Third, they are from the point of view of building industry, became indispensable to the region. It was discussed the process that the carpenters of the Edo era were inherited and accumulated the technology in this paper.

In order to build the architecture, it requires a huge amount of costs and a large number of labor force. Thus, it was possible that only the privileged classes acquire the means of production. As a result, techniques for carpenter was concentrated in a particular institution. A nd it was a nation and temples from ancient times through the Middle A ges. When it comes to the early modern period, private carpenter has emerged. It is academic challenges whether the technology among them is how inherited and accumulation. 